\title{
New Amylase Inhibitor Present in Corn Seeds Active In Vitro Against Amylase from Fusarium verticillioides
}

Edson L. Z. Figueira, Universidade Estadual de Londrina. Campus Universitário. Caixa Postal 6001, CEP 86051990, Londrina-PR, Brazil; Alejandro Blanco-Labra, Centro de Investigación y de Estudios Avanzados del IPN, Unidad Irapuato. Apdo. Postal 629, 36500 Irapuato-Gto, Mexico; Antônio Carlos Gerage, Instituto Agronômico do Paraná. Caixa Postal 481 - CEP 86001-970, Londrina-PR, Brazil; Elisabete Y. S. Ono, Universidade Estadual de Londrina. Campus Universitário. Caixa Postal 6001, CEP 86051-990, Londrina-PR, Brazil; Elizabeth Mendiola-Olaya, Centro de Investigación y de Estudios Avanzados del IPN, Unidad Irapuato. Apdo. Postal 629, 36500 Irapuato-Gto, Mexico; Yoshio Ueno, Yashio Institute of Environmental Sciences, Usui Bldg. 2F, 8-10 NishiGokencho, Shinjuku-ku, Tokio 162-0812, Japan; and Elisa Y. Hirooka, Universidade Estadual de Londrina. Campus Universitário. Caixa Postal 6001, CEP 86051-990, Londrina-PR, Brazil

\begin{abstract}
Figueira, E. L. Z., Blanco-Labra, A., Gerage, A. C., Ono, E. Y. S., Mendiola-Olaya, E., Ueno, Y., and Hirooka, E. Y. 2003. New amylase inhibitor present in corn seeds active in vitro against amylase from Fusarium verticillioides. Plant Dis. 87:233-240.

A screening for specific amylase inhibitor levels against amylase from Fusarium verticillioides (Fusarium moniliforme), the most relevant mycotoxigenic fungus in corn, was conducted on 37 corn hybrids. The amylase inhibitor levels in these hybrids ranged from 5.5 to 16.0 amylase inhibitor units per gram of corn (AIU/g) in the MASTER and AG5011 hybrids, respectively. The hybrid with the maximum content of inhibitor was used as the source of this new protein. The inhibitor was partially purified using fractional precipitation, gel filtration on Sephadex G75 column, high performance liquid chromatography (HPLC) Superose HR 10/30 column, and HPLC anion exchange chromatography, obtaining a 20.7-fold purification. Electrophoresis after denaturing and heating under reductive conditions showed an apparent $23.8 \mathrm{kDa}$ molecular mass and an acidic isoelectric point of 5.4, which differs from previous molecular masses reported for other inhibitors present in corn seeds ( 14 and $22 \mathrm{kDa}$ ). This inhibitor showed activity against amylases from human saliva and pancreas, from the fungi $F$. verticillioides and Aspergillus flavus, and from the insects Acanthoscelides obtectus, Zabrotes subfasciatus, Tribolium castaneum, and Sitotroga cerealella. The mycoflora found in the corn grain indicated Fusarium sp. as the most prevalent fungi ( $81.1 \%$ of the samples), with a count ranging from $1.5 \times 10^{2}$ to $2.4 \times 10^{6} \mathrm{CFU} / \mathrm{g}$ of corn. The presence of fumonisins was detected in 21 out of the 37 hybrids studied, ranging from 0.05 to $2.67 \mu \mathrm{g}$ of FB per gram of corn. No correlation could be established between this amylase inhibitor level in the corn seeds and the presence of Fusarium sp. or with the fumonisin content under the experimental conditions of the test.
\end{abstract}

Corn (Zea mays L.) is an important staple food in different regions of the world. Its economical importance is also relevant for its use as feed, mainly in the economically developed countries (23). However, its nutritional characteristics also expose it to the constant attack of fungi and insect predators (40).

Fusarium verticillioides, $F$. proliferatum, F. oxysporum, F. graminearum, Aspergillus flavus, A. parasiticus, Cladosporium sp., and Penicillium sp. are the most common seedborne corn mycoflora, with $F$. verticillioides being the most frequent fungus present in corn kernels $(14,20,22)$. A major problem related to fungal attack in corn is

Corresponding author: Alejandro Blanco-Labra E-mail: ablanco@ira.cinvestav.mx

Accepted for publication 26 August 2002.

Publication no. D-2002-1216-04R

(C) 2003 The American Phytopathological Society the production of toxic secondary metabolites, particularly fumonisin, zearalenone, and aflatoxin, produced by $F$. verticillioides, F. graminearum, and A. flavus, respectively $(33,34)$. Zearalenone is an estrogenic compound that produces infertility and other reproductive problems in swine (21). Aflatoxin has powerful teratogenic, mutagenic, and hepatocarcinogenic effects $(39,42)$, while fumonisins are reported to have cancer-promoting activity, in addition to causing several diseases in animals $(5,26)$. The co-occurrence of fumonisin with aflatoxin $\mathrm{B}_{1}\left(\mathrm{AFB}_{1}\right)$ is presumed to play an important role in the promotion of carcinogenesis (37). Both fungal and mycotoxin contamination are currently regarded as the primary concern in the effort to reduce problems in the global trading of agricultural commodities.

Increasing natural defense in plants can improve agricultural productivity and food safety by reducing the intensive use of pesticides, as well as the mycotoxin production in the commodities $(7,12,16)$. Spe- cial attention has been given to enzymatic inhibitors, with emphasis on $\alpha$-amylase inhibitor (AI), whose study in corn started in the 1980, when a proteinaceous AI active against insect $\alpha$-amylases was described (2). Blanco-Labra et al. (1) characterized a bifunctional protein with molecular mass of $12 \mathrm{kDa}$, which inhibited insect $\alpha$-amylase from Tribolium castaneum and Callosobruchus maculatus as well as the bovine and fungal proteases from Aspergillus niger and A. fumigatus. Chen et al. (7) reported the presence of a trypsin inhibitor in corn which was active on $\alpha$-amylase synthesis in A. flavus as well as on its activity, affecting also its fungal growth. These results demonstrated the promising potential of natural defense mechanisms for practical use. The importance of corn in the food chain, associated with the risk of serious mycotoxin hazards, has pointed out the relevance of producing new hybrids with particular resistance for the control of this fungi $(11,12)$.

Previous reports have shown the presence of $\mathrm{AFB}_{1}$ in $12.3 \%$ of the corn samples taken from several Brazilian states (29). A high occurrence of $F$. verticillioides associated with natural fumonisin contamination has also been found in corn in the State of Paraná, which produces $25 \%$ of the corn crop in Brazil (27).

The aim of this work was to evaluate the level of AI in corn, found to be active in vitro against $F$. verticillioides amylase, and to study its possible relation with fungi and fumonisin contamination in corn kernels of 37 hybrids belonging to the 1997 interseasonal crop. The isolation and partial characterization of the AI extracted from the hybrid with the highest AI activity against F. verticillioides is also presented.

\section{MATERIALS AND METHODS}

Corn hybrids. The 37 freshly harvested corn hybrids from the 1997 interseasonal crop (planting in March, harvesting in September) were screened for AI, fumonisin, and fungal contamination. These hybrids were cultivated at the experimental station of the Agronomy Institute of Paraná 
(IAPAR), Brazil, located in the northern region of the State of Paraná, Brazil $\left(23^{\circ} 19^{\prime} 00^{\prime \prime} \mathrm{S} ; 51^{\circ} 22^{\prime} 00^{\prime \prime} \mathrm{W}-\mathrm{GR}\right.$, altitude $576 \mathrm{~m})$. The corn kernels were left to dry at field temperature to $14 \%$ moisture content and stored at $-20^{\circ} \mathrm{C}$.

Amylase source. Amylase from the mycotoxigenic fungi was isolated from $F$. verticillioides (F. moniliforme strain $113 \mathrm{~F}$ ) cultures and A. flavus randomly isolated from feeds involved in animal intoxications. The strains were maintained in potato dextrose agar (PDA) at $4^{\circ} \mathrm{C}$. Crude amylase was obtained by growing the fungi in corn medium as described by Figueira and Hirooka (10). The fungus was inoculated into $480 \mathrm{ml}$ of corn medium, consisting of $2 \%$ ground corn in the supernatant of milky stage corn and incubated for 20 days at $25^{\circ} \mathrm{C}$. The culture medium was centrifuged at $5,000 \times g$ for $10 \mathrm{~min}$ at $4^{\circ} \mathrm{C}$, using the supernatant as source of amylase.

Human salivary $\alpha$-amylase and pancreatic $\alpha$-amylase were obtained from Pharmacia Diagnostics (Uppsala, Sweden), and barley $\beta$-amylase was obtained from Sigma Chemical Co. (St. Louis, MO). Amylases from different insects were obtained according to Blanco-Labra et al. (1). Insects were provided by the insectary at Cinvestav-Irapuato Unit. Insect cultures of
Prostephanus truncatus, Sitotroga cerealella, and Sitophilus zeamais were maintained on whole maize seeds, while Tribolium castaneum was grown on maize flour. Zabrotes subfasciatus and Acanthoscelides obtectus cultures were grown on whole navy bean. All cultures were maintained in a growth chamber at $28^{\circ} \mathrm{C}$ with a relative humidity of 65 to $75 \%$. For amylases extraction, the acetone-defatted larvae of the corresponding insects were homogenized with different buffer solutions in a 1:5 (wt/vol) ratio. In the case of $P$. truncatus amylase, it was extracted with a $0.1 \mathrm{M} \mathrm{NaCl}$ in $0.04 \mathrm{M}$ succinic acid, $\mathrm{pH}$ 6.5 , solution. The amylases from Sitophilus zeamais, T. castaneum, Z. subfasciatus, Sitotroga cerealella, and Acanthoscelides obtectus, were extracted with $0.2 \mathrm{M}$ succinic acid buffer, $\mathrm{pH} 4.5$. The suspensions were centrifuged at $10,000 \times g$ for $10 \mathrm{~min}$ at $4^{\circ} \mathrm{C}$, and the supernatants were used as source of amylase.

Amylase from corn was extracted with $0.01 \mathrm{M} \mathrm{CaCl}_{2}+0.1 \mathrm{M} \mathrm{NaCl}$ solutions, from 5-day-old germinated seeds.

Microbiological analysis. One kilogram of corn kernel was homogenized, and a representative sample was finely ground. Ten grams were blended with $90 \mathrm{ml}$ of sterile $0.1 \%$ peptone water (wt/vol), and serial dilutions up to $10^{-6}$ were carried out.

Table 1. Amylase inhibitor levels active against Fusarium moniliforme amylase in different corn hybrids

\begin{tabular}{llll}
\hline Hybrid & $\begin{array}{l}\text { Inhibition level } \\
(\mathbf{A I U} / \mathbf{g})^{\mathbf{w}}\end{array}$ & Hybrid & $\begin{array}{l}\text { Inhibition level } \\
(\mathbf{A I U} / \mathbf{g})\end{array}$ \\
\hline AG5011 & $15.97 \pm 0.42 \mathrm{a} \mathrm{a}^{\mathrm{x}}$ & DINA766 & $9.76 \pm 0.42 \mathrm{~g}-\mathrm{j}$ \\
ZEN8490 & $15.54 \pm 1.03 \mathrm{a}$ & EXCELER & $9.75 \pm 0.71 \mathrm{~g}-\mathrm{j}$ \\
XL360 & $14.07 \pm 0.16 \mathrm{ab}$ & AG3010 & $9.71 \pm 0.69 \mathrm{~g}-\mathrm{j}$ \\
XL220 & $14.05 \pm 0.48 \mathrm{ab}$ & DENSUS & $9.71 \pm 0.82 \mathrm{~g}-\mathrm{j}$ \\
FT9006 & $13.93 \pm 0.22 \mathrm{a}-\mathrm{c}$ & AS32 & $9.69 \pm 0.23 \mathrm{~g}-\mathrm{j}$ \\
XL Exp9663 & $13.82 \pm 0.75 \mathrm{a}-\mathrm{c}$ & BR205 & $9.67 \pm 0.30 \mathrm{~g}-\mathrm{k}$ \\
AGX9682 & $13.24 \pm 1.80 \mathrm{~b}-\mathrm{d}$ & AGX9632 & $9.54 \pm 0.99 \mathrm{~g}-\mathrm{k}$ \\
XL221 & $12.91 \pm 0.71 \mathrm{~b}-\mathrm{e}$ & AS3466 & $9.46 \pm 0.52 \mathrm{~h}-\mathrm{k}$ \\
DINA556 & $12.51 \pm 0.43 \mathrm{~b}-\mathrm{f}$ & AG122 & $9.45 \pm 0.81 \mathrm{~h}-\mathrm{k}$ \\
C435 & $12.42 \pm 0.98 \mathrm{~b}-\mathrm{f}$ & P3071 & $9.31 \pm 0.64 \mathrm{i}-\mathrm{k}$ \\
FT9043 & $11.75 \pm 0.72 \mathrm{c}-\mathrm{g}$ & ZEN8202 & $9.29 \pm 0.42 \mathrm{i}-\mathrm{k}$ \\
C625 & $11.65 \pm 0.51 \mathrm{c}-\mathrm{h}$ & DINA1000 & $9.16 \pm 0.16 \mathrm{i}-1$ \\
ZEN8392 & $11.26 \pm 0.47 \mathrm{~d}-\mathrm{i}$ & BR3123 & $8.54 \pm 0.70 \mathrm{j}-\mathrm{m}$ \\
C701 & $10.82 \pm 0.87 \mathrm{e}-\mathrm{i}$ & BR206 & $8.38 \pm 0.75 \mathrm{j}-\mathrm{m}$ \\
C333 & $10.57 \pm 0.68 \mathrm{f}-\mathrm{j}$ & P3027 & $7.46 \pm 0.67 \mathrm{k}-\mathrm{n}$ \\
P3041 & $10.56 \pm 0.15 \mathrm{f}-\mathrm{j}$ & XL345 & $6.98 \pm 1.47 \mathrm{l}-\mathrm{n}$ \\
DINA769 & $10.43 \pm 0.85 \mathrm{f}-\mathrm{j}$ & ZEN8501 & $6.70 \pm 0.53 \mathrm{mn}$ \\
C901 & $10.33 \pm 1.02 \mathrm{f}-\mathrm{j}$ & MASTER & $5.48 \pm 0.36 \mathrm{n}$ \\
SG150 & $10.10 \pm 0.80 \mathrm{~g}-\mathrm{i}$ & & \\
\hline
\end{tabular}

${ }^{\mathrm{w}} \mathrm{AIU} / \mathrm{g}=$ units of amylase inhibitor activity of corn on a dry weight basis (means $\pm \mathrm{SD} ; \mathrm{n}=3$ ).

${ }^{x}$ Numbers in columns followed by the same letter are not significantly different according to the Tukey test $(P<0.05)$.

Table 2. Corn amylase inhibitor purification steps

\begin{tabular}{lccc}
\hline Procedure & $\begin{array}{c}\text { Specific activity } \\
\text { (AIU/mg of protein) }\end{array}$ & $\begin{array}{c}\text { Yield } \\
(\boldsymbol{\%})\end{array}$ & $\begin{array}{c}\text { Purification } \\
\text { folds }\end{array}$ \\
\hline Crude extract & 5.5 & 100.0 & 1.0 \\
Ammonium sulfate fractionation & 8.7 & 57.6 & 1.6 \\
Gel filtration (G-75) & 10.3 & 17.4 & 1.9 \\
Gel filtration-HPLC & 38.0 & 17.4 & 6.9 \\
Ion exchange-HPLC & 113.4 & 3.6 & 20.7 \\
\hline
\end{tabular}

y Units of amylase inhibitor activity per mg of protein.

${ }^{\mathrm{z}}$ High performance liquid chromatography.
One milliliter of each dilution was inoculated in PDA, $\mathrm{pH} 4.0$, supplemented with chloramphenicol at $50 \mu \mathrm{g} / \mathrm{ml}$. After 6 days incubation at $25^{\circ} \mathrm{C}$, the total fungal count, Fusarium sp.-like colonies, and other fungi were visually determined (CFU/g) according to Samson et al. (30).

Fumonisin determination. Fumonisin $\mathrm{B}_{1}\left(\mathrm{FB}_{1}\right)$ and $\mathrm{B}_{2}\left(\mathrm{FB}_{2}\right)$ were analyzed by high performance liquid chromatography (HPLC) according to the method of Shephard et al. (35), as modified by Ueno et al. (38). Corn seeds $(10 \mathrm{~g})$ ground to pass a 50 mesh size were mixed with $30 \mathrm{ml}$ of methanol-water $(3: 1 \mathrm{vol} / \mathrm{vol})$. The suspension was shaken at $150 \mathrm{rpm}$ for $30 \mathrm{~min}$ and centrifuged at $4,500 \times g$ for $10 \mathrm{~min}$. The crude extract was cleaned with a Sep Pak accell plus QMA cartridge (Waters Co., Ltd., Massachusetts), and the fumonisins were eluted with $10 \mathrm{ml}$ of methanol containing $0.5 \%$ acetic acid. The eluate was evaporated to dryness under a nitrogen stream at $40^{\circ} \mathrm{C}$, and the residue was dissolved in methanol-water $(3: 1 \mathrm{vol} / \mathrm{vol})$ and derivatized with $o$-phthaldialdehyde. The fumonisins were analyzed with a reversephase isocratic HPLC system, using a Shim-pack CLC-ODS (M) column $(4.6 \times$ $250 \mathrm{~mm}$, Shimadzu, Tokyo-Japan). Excitation and emission wavelengths were 335 $\mathrm{nm}$ and $450 \mathrm{~nm}$, respectively. The eluent was $\mathrm{CH}_{3} \mathrm{OH}: 0.1 \quad \mathrm{M} \quad \mathrm{NaH}_{2} \mathrm{PO}_{4} \quad$ (80:20 $\mathrm{vol} / \mathrm{vol}$ ) adjusted to $\mathrm{pH} 3.3$ with ortophosphoric acid. The flow rate was 1 $\mathrm{ml} / \mathrm{min}$. The lowest detection limits for $\mathrm{FB}_{1}$ and $\mathrm{FB}_{2}$ were $50 \mathrm{ng} / \mathrm{g}$ and $80 \mathrm{ng} / \mathrm{g}$, respectively. Total fumonisin content was calculated as the sum of $\mathrm{FB}_{1}$ and $\mathrm{FB}_{2}$.

Corn amylase inhibitor extraction procedure. Finely ground corn seeds (48 mesh in a Janke \& Kunkel model A10 mill) were 4-times defatted by shaking them with acetone $(1: 1 \mathrm{vol} / \mathrm{vol})$ for $15 \mathrm{~min}$ and decanted. The defatted flour was dried at room temperature and stored at $-20^{\circ} \mathrm{C}$. This corn flour $(20 \mathrm{~g})$ was mixed with 100 $\mathrm{ml}$ of $0.1 \mathrm{M}$ acetate buffer, $\mathrm{pH} 6.0$, and continuously stirred for $90 \mathrm{~min}$ at $4{ }^{\circ} \mathrm{C}$. The soluble proteins were obtained by centrifuging at $30,000 \times g$ for $20 \mathrm{~min}$ at $4^{\circ} \mathrm{C}$ and precipitating them by adding ammonium sulfate to reach $60 \%$ saturation. After standing for $12 \mathrm{~h}$ at $4^{\circ} \mathrm{C}$, the precipitate was recovered by centrifuging at $30,000 \times$ $g$ for $20 \mathrm{~min}$ at $4^{\circ} \mathrm{C}$. The pellet was dissolved in $6 \mathrm{ml}$ of $0.05 \mathrm{M} \mathrm{KH}_{2} \mathrm{PO}_{4}-\mathrm{NaOH}$ buffer, $\mathrm{pH}$ 6.7, and dialyzed extensively against the same buffer. The sample was centrifuged at $15,000 \times g$ for $15 \mathrm{~min}$ at $4^{\circ} \mathrm{C}$ and the supernatant stored at $-20^{\circ} \mathrm{C}$.

Amylase and amylase inhibitor activity. Amylase inhibitor screening in the 37 corn hybrids: amylase activity was analyzed by the iodometric method (41). One unit of amylase (AU) activity was defined as the amount of enzyme that hydrolyzed $0.1 \mathrm{mg}$ of starch in $10 \mathrm{~min}$ at $40^{\circ} \mathrm{C}$, when $5.0 \mathrm{mg}$ of starch was present.

The AI activity was analyzed by prein- 
cubating $0.25 \mathrm{ml}$ of fungal amylase after appropriate dilution (corresponding to 15 AU) with $0.25 \mathrm{ml}$ of corn extract, also after appropriate dilution, to obtain a $50 \%$ reduction of the original amylase activity. Then they were incubated for $30 \mathrm{~min}$ at $40^{\circ} \mathrm{C}$, and the residual amylase activity was determined. One unit of AI activity (AIU) was defined as the amount of protein that inhibited $1 \mathrm{AU}$ of fungal amylase under the assay conditions described, and was expressed as AIU/g of corn on dry weight basis.

Amylase inhibitor purification and characterization. Amylase activity was analyzed by the iodometric method (41) modified as a micro method for a microplate determination, where the AI activ- ity was analyzed by preincubating the AI with fungal amylase (corresponding 0.2 AU) in a final volume of $70 \mu \mathrm{l}$, to obtain $50 \%$ reduction of the original amylase activity. Then, samples were incubated for $10 \mathrm{~min}$ at $25^{\circ} \mathrm{C}$, and the residual amylase activity determined. One unit of AI activity (AIU) was defined as the amount of protein that inhibited $1 \mathrm{AU}$ of fungal amylase under the assay conditions described.

One unit of amylase (AU) activity was defined as the amount of enzyme that hydrolyzed $0.1 \mathrm{mg}$ of starch in $60 \mathrm{~min}$ at $25^{\circ} \mathrm{C}$, when $0.038 \mathrm{mg}$ of starch was present.

Amylase inhibitor extraction and partial purification. Corn hybrid AG5011 was selected as the source of AI, based on its high inhibitory activity on $F$. verticillioides amylase. Defatted corn flour (100 g) was extracted with $500 \mathrm{ml}$ of $0.1 \mathrm{M}$ acetate buffer, $\mathrm{pH} 6.0\left(12 \mathrm{~h}\right.$ at $\left.4^{\circ} \mathrm{C}\right)$. The soluble proteins were obtained after centrifuging at $30,000 \times g$ for $20 \mathrm{~min}$ at $4^{\circ} \mathrm{C}$ and submitted to fractionated precipitation with ammonium sulfate (30 to $60 \%$ saturation). The precipitate $\left(\mathrm{P}_{30-60}\right)$ was recovered by centrifuging at $30,000 \times g$ for $20 \mathrm{~min}$ at $4^{\circ} \mathrm{C}$ and dissolving the pellet in $0.01 \mathrm{M}$

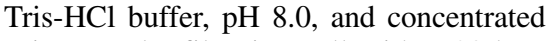
using an ultrafiltration cell with a $30-\mathrm{kDa}$ molecular mass exclusion membrane.

The concentrated sample was fractionated on a Sephadex G-75 gel filtration column $(166 \times 1.6 \mathrm{~cm})$, equilibrated with $0.01 \mathrm{M}$ ammonium bicarbonate buffer, $\mathrm{pH}$

\section{A}

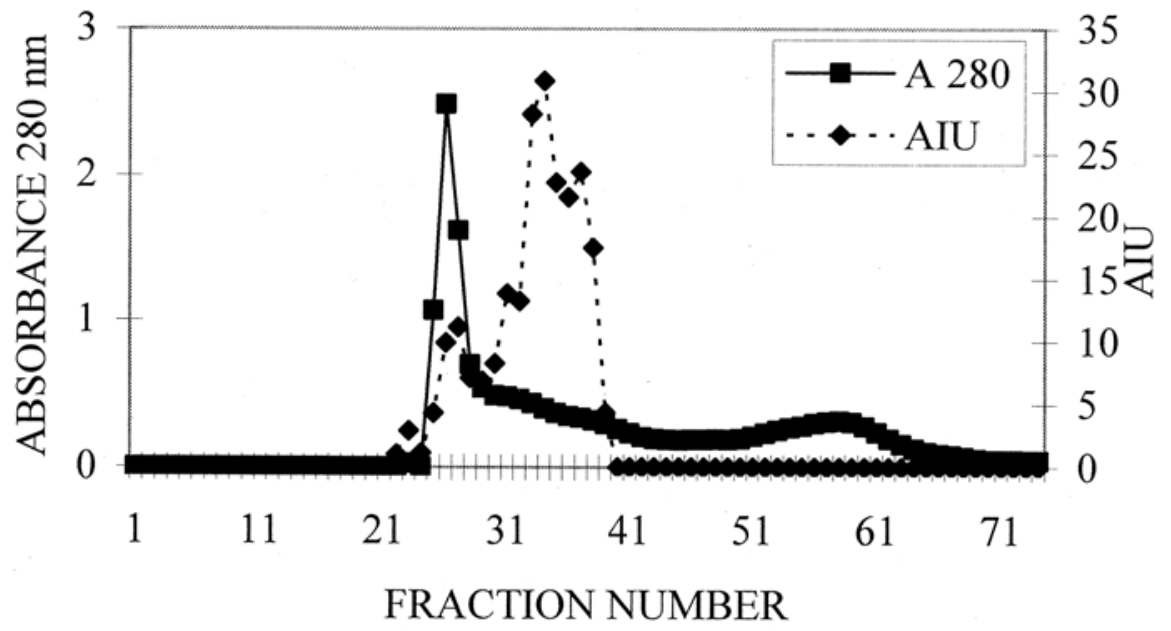

B

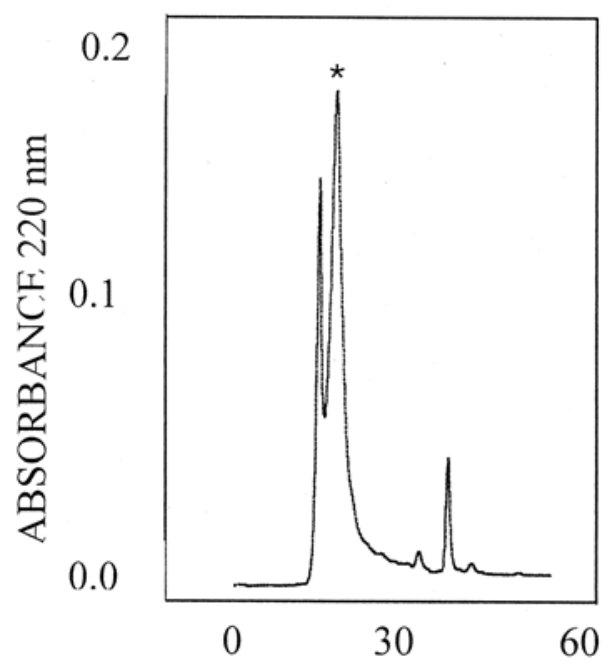

TIME (min)

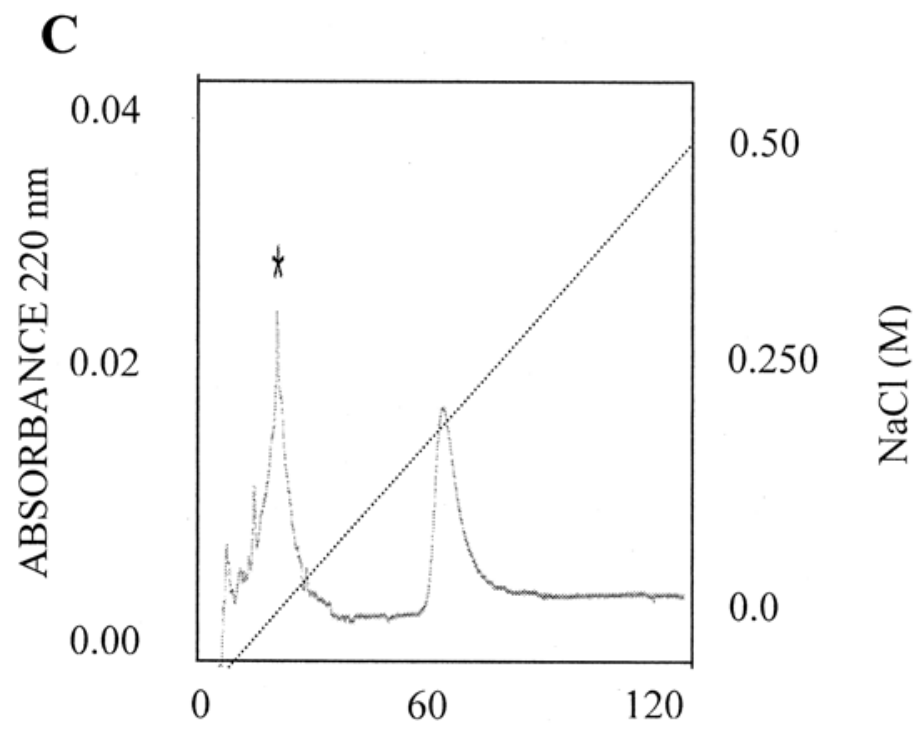

TIME (min)

\section{* Active peak}

Fig. 1. A, Sephadex G-75 gel filtration chromatography of fraction $\mathrm{P}_{30-60}(166 \times 1.6 \mathrm{~cm}$ column). B, high performance liquid chromatography (HPLC)Superose 12 HR 10/30 column from Sephadex G-75 chromatography active pool. C, HPLC-anionic exchange column Vydac 300 VHP 575 from the Superose chromatography active peak. 
8.2, and the elution was carried out at a flow rate of $15 \mathrm{ml} / \mathrm{h}$, collecting $7-\mathrm{ml}$ fraction. Protein content was monitored at 280 nm. The active fractions (against $F$. verticillioides amylase) were pooled and dried. The pellet was solubilized in $0.01 \mathrm{M}$ Tris$\mathrm{HCl}$ buffer, $\mathrm{pH} 7.5$, and fractionated in an HPLC system fitted with a Superose 12
HR 10/30 (Pharmacia Biotech, Uppsala, Sweden) equilibrated with the same buffer. The elution was carried out at a flow rate of $0.4 \mathrm{ml} / \mathrm{min}$, and the active peak was collected and concentrated by ultrafiltration cell using a $10-\mathrm{kDa}$ molecular mass exclusion membrane. This solution was used for the inhibitor characterization. The active sample was applied into an HPLC system fitted with an anionic exchange column Vydac 300 VHP $575(0.75 \mathrm{~cm}$ i.d. $\times 5.0 \mathrm{~cm})$ equilibrated with $0.01 \mathrm{M}$ Tris$\mathrm{HCl}, \mathrm{pH}$ 7.5. Separation was performed using a linear $\mathrm{NaCl}$ gradient in the same buffer ( 0 to $0.5 \mathrm{M} \mathrm{NaCl}$ in $120 \mathrm{~min}$ ). The separation was monitored by UV absorb-

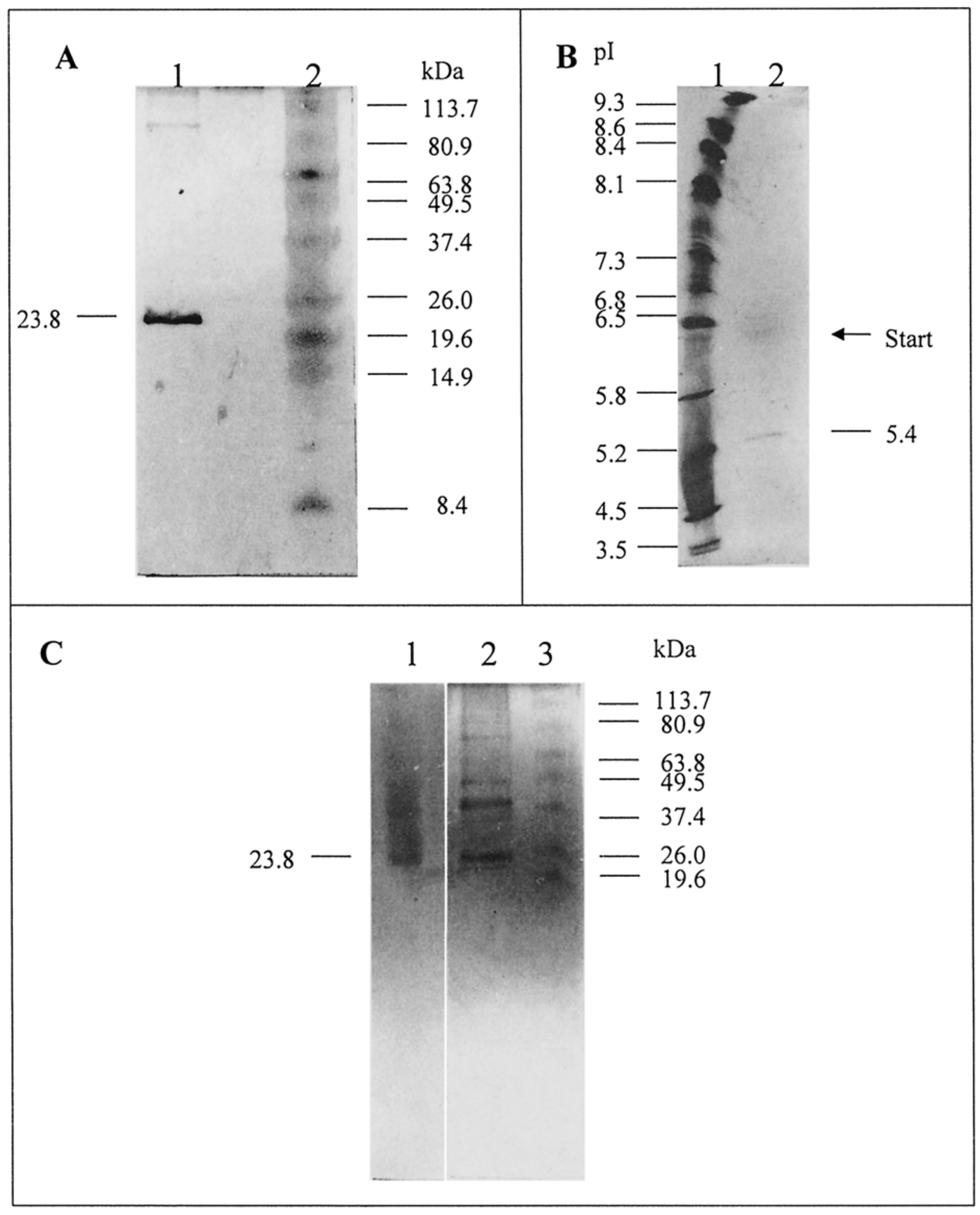

Fig. 2. A, Sodium dodecyl sulfate-polyacrylamide gel electrophoresis (SDS-PAGE) of the amylase inhibitor (AI) active peak from high performance liquid chromatography (HPLC)-anion exchange column Vydac 300 VHP 575. Line 1: AI. Line 2: Molecular mass markers. B, Isoelectric focusing of the AI active peak from HPLC-anion exchange column Vydac 300 VHP 575. Line 1: isoelectric point (pI) markers. Line 2: AI. C, AI zymogram on SDS-PAGE of the inhibitor. Line 1: AI activity from active pool from Sephadex G-75 gel filtration chromatography. Line 2: Protein from active pool from Sephadex G-75 gel filtration chromatography. Line 3: Molecular mass markers. 
ance at $220 \mathrm{~nm}$. The active peak was collected and stored at $-20^{\circ} \mathrm{C}$. This fraction was used to determine the isoelectric point and the apparent molecular mass. Total soluble protein recuperation in each purification step was determined by the Bradford (4) method.

Preincubating time effect. Constant amounts $(1.54 \mu \mathrm{g})$ of AI were preincubated with $0.05 \mathrm{M} \mathrm{KH}_{2} \mathrm{PO}_{4}-\mathrm{NaOH}$ buffer $(\mathrm{pH}$ 6.7) for $0,5,10,20$, and $30 \mathrm{~min}$, with constant amounts of amylase from $F$. verticillioides, prior to the addition of the substrate, and the remaining amylase activity was determined.

Thermal stability. Constant amounts $(1.54 \mu \mathrm{g})$ of AI were preincubated with $0.05 \mathrm{M} \mathrm{KH}_{2} \mathrm{PO}_{4}-\mathrm{NaOH}$ buffer ( $\mathrm{pH}$ 6.7) for $30 \mathrm{~min}$ at $25,40,70$, and $94^{\circ} \mathrm{C}$, then immediately cooled and preincubated for 10 min with amylase from $F$. verticillioides at $25^{\circ} \mathrm{C}$, and the remaining amylase activity was determined.

pH effect. To determine the $\mathrm{pH}$ effect on the activity of $F$. verticillioides amylase, AI $(1.54 \mu \mathrm{g})$ activity was measured at different pHs (4.0, 5.0, 6.0, 7.0, 8.0, 9.0), using the following $0.05 \mathrm{M}$ buffers: sodium acetate, $\mathrm{pH} 4.0$ and 5.0; sodium phosphate, $\mathrm{pH} 6.0$ and 7.0; and Tris- $\mathrm{HCl}$, $\mathrm{pH} 8.0$ and 9.0. The AI and the enzyme were kept constant (0.2 AU). The AI together with the amylase was preincubated at each one of these $\mathrm{pHs}$ for $10 \mathrm{~min}$ at $25^{\circ} \mathrm{C}$, and the remaining amylase activity was determined at the corresponding $\mathrm{pH}$.

Molecular mass determination. The apparent molecular mass of the purified AI was measured by sodium dodecyl sulfatepolyacrylamide gel electrophoresis (SDSPAGE) according to Schagger \& Von Jagow (32), using 4\% acrylamide for the stacking gel and $13 \%$ (wt/vol) for the separating gel, and the gels were silver-stained using the method of Blomm et al. (3), and the molecular mass was determined using the software Quantity One 4.2.1 (Bio-Rad Laboratories, Richmond, CA).

Zymogram was performed under the same electrophoretic conditions. Activity was detected after washing the gel with $0.05 \mathrm{M} \mathrm{KH}_{2} \mathrm{PO}_{4}-\mathrm{NaOH}$ buffer, $\mathrm{pH}$ 6.7, containing $2.5 \%$ Triton $\mathrm{X}-100$ for $30 \mathrm{~min}$ at room temperature. Then the gel was immersed in a solution prepared with crude $F$. verticillioides amylase in a $0.05 \mathrm{M}$

Table 3. Amylase inhibitor thermostability after 30 min of thermal treatment

\begin{tabular}{lc}
\hline Temp. $\left({ }^{\circ} \mathbf{C}\right)$ & Inhibition $(\%)^{\mathbf{x}}$ \\
\hline 25 & $100.0 \pm 7.5 \mathrm{a}^{\mathrm{y}}$ \\
40 & $112.2 \pm 9.2 \mathrm{a}$ \\
70 & $69.8 \pm 5.1 \mathrm{~b}$ \\
94 & $52.0 \pm 2.9 \mathrm{c}$ \\
\hline
\end{tabular}

x Relative value compared with $25^{\circ} \mathrm{C}$ treatment (means $\pm \mathrm{SD} ; \mathrm{n}=3$ ).

${ }^{y}$ Numbers in columns followed by the same letter are not significantly different according to the Tukey test $(P<0.05)$.
$\mathrm{KH}_{2} \mathrm{PO}_{4}-\mathrm{NaOH}$ buffer, $\mathrm{pH} 6.7$ (620 AU) and allowed to react for $120 \mathrm{~min}$ at room temperature. The gel was washed and incubated $150 \mathrm{~min}$ in a $0.5 \%$ starch-agarose gel. The AI activity band was stained after immersing the starch-agarose gel into a $0.5 \% \mathrm{I}_{2}, 5 \% \mathrm{KI}$ solution. The presence of the AI showed as a colored band.

Isoelectric focusing determination. The isoelectric point ( $\mathrm{pI}$ ) of the purified AI was determined using a Phast-System instrument (Pharmacia) operating with Phast Media IEF 3-9, which allows separation at a $\mathrm{pH}$ range from 3 to 9 . The samples were run as described by the manufacturer (Separation Technique File No. 100). The bands were visualized by silver nitrate staining after IEF, and the pI was determined using the software Quantity One 4.2.1 (Bio-Rad).

Specificity. The specificity of AI was evaluated against amylase from different sources: F. verticillioides, A. flavus, human salivary and pancreatic $\alpha$-amylase, germinated corn, barley $\beta$-amylase, and the insects Sitophilus zeamais, T. castaneum, $Z$. subfasciatus, Acanthoscelides obtectus, $P$. truncatus, and Sitotroga cerealella. AI $(1.54 \mu \mathrm{g})$ with the corresponding amylase was preincubated for $30 \mathrm{~min}$ at room temperature in $0.05 \mathrm{M}$ sodium phosphate buffer, $\mathrm{pH}$ 7.0, for human saliva, pancreatic $\alpha$-amylase, and $F$. verticillioides amylase; or $0.05 \mathrm{M}$ sodium phosphate buffer, $\mathrm{pH}$ 6.0, for A. flavus, Acanthoscelides $o b$ tectus, Z. subfasciatus, and T. castaneum amylase; or $0.05 \mathrm{M}$ sodium acetate buffer, $\mathrm{pH} 5.0$, for corn amylase, barley $\beta$ amylase, Sitotroga cerealella, Sitophilus zeamais, and P. truncatus amylase; and the remaining amylase activity was determined.

Moisture content. Ten grams of defatted corn flour was dried at $105^{\circ} \mathrm{C}$ until constant weight in an infrared analyzer (OHAUS, model MB2000). The moisture content, expressed in percentage, was used to calculate the level of AI on dry weight basis.
Statistical analysis. AI content in the hybrids was analyzed and compared using SAS version 6.12 (31). The Tukey's multiple comparison test was applied whenever the significant difference was $P<0.05$. The correlation among AI, Fusarium sp., and fumonisin level was also determined.

\section{RESULTS}

AI activity against $F$. verticillioides amylase was monitored in all 37 hybrid samples (Table 1). Analysis showed a significant difference in AI content $(P<0.05)$ among the hybrids tested. The AI level ranged from 5.5 to $16.0 \mathrm{AIU} / \mathrm{g}$ of corn, with minimal and maximal value being observed for the MASTER and AG5011 hybrids, respectively, with a variation coefficient of $6.5 \%$ and a minimal significant difference of 1.2 (Table 1).

The hybrid AG5011, which showed the highest level of AI, was selected as the source of AI. Table 2 summarizes the results of the partial isolation procedure. After ammonium sulfate precipitation (30 to $60 \%$ saturation) and ultrafiltration, the fraction obtained was submitted to gel filtration on a Sephadex G-75 column chromatography. The active fractions were

Table 4. Amylase inhibitor activity measured against amylases from different sources

\begin{tabular}{lc}
\hline Amylase source & Specific activity \\
\hline Human salivary & $27.7 \pm 7.5$ \\
Human pancreatic & $14.3 \pm 4.6$ \\
Fusarium verticillioides & $28.8 \pm 7.2$ \\
Aspergillus flavus & $68.2 \pm 1.7$ \\
Acanthoscelides obtectus & $51.3 \pm 7.5$ \\
Zabrotes subfasciatus & $57.6 \pm 2.6$ \\
Tribolium castaneum & $21.8 \pm 2.3$ \\
Sitotroga cerealella & $22.7 \pm 0.9$ \\
Sitophilus zeamais & $-{ }^{\mathrm{z}}$ \\
Prostephanus truncatus & - \\
Germinated corn & - \\
Barley $\beta$-amylase & - \\
\hline
\end{tabular}

${ }^{y}$ Units of amylase inhibitor activity per mg of protein: means $\pm \mathrm{SD} ; \mathrm{n}=3$.

z Not detected.

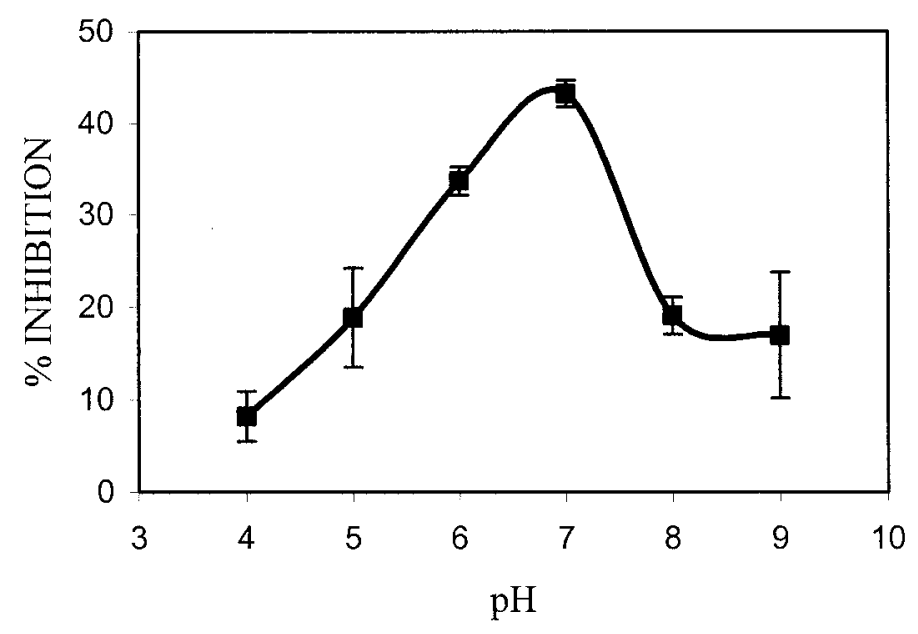

Fig. 3. Effect of varying $\mathrm{pH}$ on the interaction of Fusarium verticillioides amylase and the amylase inhibitor. 
Table 5. Fungi and fumonisin contamination in different corn hybrids (1997 interseasonal crop)

\begin{tabular}{|c|c|c|c|c|c|c|c|}
\hline \multirow[b]{2}{*}{ Corn hybrid } & \multicolumn{6}{|c|}{ Fungal count $(\mathrm{CFU} / \mathrm{g})$} & \multirow{2}{*}{$\begin{array}{c}\text { Fumonisin }{ }^{y} \\
(\mu \mathrm{g} \text { FB/g corn })\end{array}$} \\
\hline & Total & Fusarium sp. & Penicillium sp. & Aspergillus sp. & Cladosporium sp. & Yeast & \\
\hline BR205 & $7.5 \times 10^{5}$ & $4.0 \times 10^{5}$ & ${ }^{z}$ & - & - & $3.5 \times 10^{5}$ & 2.67 \\
\hline AS3466 & $2.4 \times 10^{6}$ & $2.4 \times 10^{6}$ & - & - & - & - & 1.07 \\
\hline XL345 & $3.2 \times 10^{5}$ & $2.2 \times 10^{5}$ & $5.0 \times 10^{4}$ & - & - & $5.0 \times 10^{4}$ & 0.43 \\
\hline ZEN8501 & $1.8 \times 10^{5}$ & $5.5 \times 10^{4}$ & $5.0 \times 10^{3}$ & - & $5.0 \times 10^{3}$ & $1.0 \times 10^{5}$ & 0.39 \\
\hline EXCELLER & $4.9 \times 10^{5}$ & $4.5 \times 10^{5}$ & $4.0 \times 10^{4}$ & - & - & - & 0.33 \\
\hline BR3123 & $1.9 \times 10^{4}$ & $1.7 \times 10^{4}$ & $5.0 \times 10^{2}$ & - & $1.0 \times 10^{3}$ & - & 0.32 \\
\hline FT9006 & $3.5 \times 10^{5}$ & $3.3 \times 10^{5}$ & - & - & - & $1.0 \times 10^{4}$ & 0.21 \\
\hline SG150 & $1.5 \times 10^{6}$ & $1.1 \times 10^{6}$ & - & - & $5.0 \times 10^{3}$ & $3.6 \times 10^{5}$ & 0.10 \\
\hline XL360 & $5.6 \times 10^{5}$ & - & - & - & - & $5.6 \times 10^{5}$ & 0.10 \\
\hline P3071 & $1.2 \times 10^{5}$ & $3.5 \times 10^{4}$ & - & - & $5.0 \times 10^{3}$ & $7.5 \times 10^{4}$ & 0.09 \\
\hline AS32 & $6.5 \times 10^{3}$ & - & $2.5 \times 10^{3}$ & $5.0 \times 10^{2}$ & - & $1.0 \times 10^{3}$ & 0.08 \\
\hline P3041 & $2.2 \times 10^{6}$ & $2.1 \times 10^{6}$ & $2.5 \times 10^{4}$ & - & - & - & - \\
\hline AG122 & $9.5 \times 10^{5}$ & $9.0 \times 10^{5}$ & - & - & - & $5.0 \times 10^{4}$ & - \\
\hline DINA1000 & $9.0 \times 10^{5}$ & $8.5 \times 10^{5}$ & - & $5.0 \times 10^{4}$ & - & - & - \\
\hline AG5011 & $1.5 \times 10^{5}$ & - & - & - & - & $1.3 \times 10^{5}$ & - \\
\hline C333 & $1.2 \times 10^{5}$ & - & $3.0 \times 10^{3}$ & - & $5.0 \times 10^{2}$ & - & - \\
\hline MASTER & $1.2 \times 10^{5}$ & $1.5 \times 10^{4}$ & - & - & $1.0 \times 10^{4}$ & $9.0 \times 10^{4}$ & - \\
\hline DINA556 & $3.5 \times 10^{4}$ & $2.6 \times 10^{4}$ & $5.0 \times 10^{2}$ & - & - & $8.5 \times 10^{3}$ & - \\
\hline P3027 & $3.1 \times 10^{4}$ & - & - & - & $3.0 \times 10^{4}$ & $6.0 \times 10^{2}$ & - \\
\hline $\mathrm{C} 435$ & $2.7 \times 10^{4}$ & $1.0 \times 10^{3}$ & $5.0 \times 10^{3}$ & - & - & $8.0 \times 10^{3}$ & - \\
\hline BR206 & $1.2 \times 10^{3}$ & $1.5 \times 10^{2}$ & $1.0 \times 10^{2}$ & - & $5.0 \times 10^{2}$ & $4.0 \times 10^{2}$ & - \\
\hline AG3010 & $2.3 \times 10^{5}$ & $2.0 \times 10^{5}$ & $5.0 \times 10^{3}$ & - & - & $2.2 \times 10^{4}$ & 1.54 \\
\hline DINA769 & $3.7 \times 10^{5}$ & $2.1 \times 10^{5}$ & $1.5 \times 10^{4}$ & - & $1.5 \times 10^{4}$ & $1.3 \times 10^{5}$ & 0.80 \\
\hline XL220 & $7.4 \times 10^{4}$ & $5.4 \times 10^{4}$ & - & - & - & $2.0 \times 10^{4}$ & 0.58 \\
\hline XL Exp9663 & $1.2 \times 10^{6}$ & $7.0 \times 10^{5}$ & $4.0 \times 10^{5}$ & - & - & $1.0 \times 10^{5}$ & 0.49 \\
\hline DINA766 & $1.6 \times 10^{6}$ & - & $5.0 \times 10^{4}$ & - & - & $3.5 \times 10^{5}$ & 0.33 \\
\hline C901 & $9.0 \times 10^{4}$ & $3.0 \times 10^{4}$ & $1.0 \times 10^{4}$ & - & - & $3.5 \times 10^{4}$ & 0.29 \\
\hline AGX9682 & $1.0 \times 10^{6}$ & $5.0 \times 10^{5}$ & $3.5 \times 10^{5}$ & - & - & $1.5 \times 10^{5}$ & 0.16 \\
\hline ZEN8490 & $7.6 \times 10^{4}$ & $4.5 \times 10^{4}$ & - & - & - & $3.1 \times 10^{4}$ & 0.15 \\
\hline DENSUS & $1.5 \times 10^{6}$ & $9.5 \times 10^{5}$ & - & - & $5.0 \times 10^{5}$ & $5.0 \times 10^{4}$ & 0.08 \\
\hline $\mathrm{C} 701$ & $6.7 \times 10^{4}$ & $6.7 \times 10^{4}$ & - & - & - & - & 0.05 \\
\hline XL221 & $1.5 \times 10^{6}$ & $9.5 \times 10^{5}$ & $1.0 \times 10^{5}$ & - & $4.0 \times 10^{5}$ & - & - \\
\hline ZEN8202 & $3.3 \times 10^{5}$ & $9.5 \times 10^{4}$ & $2.0 \times 10^{4}$ & - & - & $2.1 \times 10^{5}$ & - \\
\hline FT9043 & $1.2 \times 10^{5}$ & - & $9.0 \times 10^{4}$ & - & - & $3.0 \times 10^{4}$ & - \\
\hline ZEN8392 & $7.6 \times 10^{4}$ & $4.0 \times 10^{3}$ & - & - & - & $7.2 \times 10^{4}$ & - \\
\hline AGX9632 & $4.9 \times 10^{4}$ & $2.4 \times 10^{4}$ & - & - & - & $2.5 \times 10^{4}$ & - \\
\hline C625 & $4.5 \times 10^{3}$ & $8.0 \times 10^{2}$ & $3.0 \times 10^{2}$ & - & $5.0 \times 10$ & $3.5 \times 10^{3}$ & - \\
\hline
\end{tabular}

y Fumonisin $\mathrm{B}_{1}\left(\mathrm{FB}_{1}\right)+\mathrm{B}_{2}\left(\mathrm{FB}_{2}\right)$.

z Not detected.

pooled and dried (Fig. 1A), resulting in a 1.9-fold increase in specific activity (Table 2). After Superose 12 HR 10/30 chromatography on HPLC, the specific activity increased 6.9-fold and the active peak (Fig. 1B) was concentrated and then applied in an anionic exchange column Vydac 300 VHP 575, resulting in an additional 20.7fold increase in specific activity (Table 2). The active peak (Fig. 1C) was used to determine the apparent molecular mass and the isoelectric point.

The relative molecular mass determined by Superose 12 HR 10/30 chromatography was $80 \mathrm{kDa}$ (data not shown). However, when this apparent molecular mass was determined by SDS-PAGE under reductive conditions and after heating the sample at $40^{\circ} \mathrm{C}$ for $30 \mathrm{~min}$, or at $94^{\circ} \mathrm{C}$ for $4 \mathrm{~min}$, an apparent molecular mass of $23.8 \mathrm{kDa}$ was found. (Fig. 2A), and this was confirmed by its zymogram (Fig. 2C). The isoelectric point, determined by Phast System (Pharmacia), showed an acid protein with a $\mathrm{pI}$ of 5.4 (Fig. 2B).

An experiment to measure the preincubation time requirement showed a $10-\mathrm{min}$ maximum (data not shown). The AI thermostability data (Table 3 ) showed a rela- tively stable protein, since it could stand temperatures up to $94^{\circ} \mathrm{C}$ for $30 \mathrm{~min}$, retaining $52 \%$ of the activity. The effect of $\mathrm{pH}$ on the inhibitory activity of the AI measured against $F$. verticillioides amylase showed a maximum at $\mathrm{pH} 7.0$ (Fig. 3).

This AI showed a broad spectrum of inhibition, displaying high inhibition to the fungi amylases from $F$. verticillioides and A. flavus, as well as amylases from some important insects, such as A. obtectus, $Z$. subfasciatus, T. castaneum, and Sitotroga cerealella. However, it did not recognize the amylases from Sitophilus zeamais and $P$. truncatus. Amylase from human saliva and human pancreas were also recognized, whereas amylases from germinating seed of corn and $\beta$-amylase from barley were not recognized (Table 4).

Mycoflora content and mycotoxin contamination in all hybrids are shown in Table 5. The total fungi and yeast count ranged from $1.2 \times 10^{3}$ to $2.4 \times 10^{6} \mathrm{CFU} / \mathrm{g}$. Fusarium sp. ( $81.1 \%$ of the samples) prevailed (range from $1.5 \times 10^{2}$ to $2.4 \times 10^{6}$ CFU/g), followed by Penicillium sp. detected in $54.1 \%$ of the samples (range from $1.0 \times 10^{2}$ to $4.0 \times 10^{5} \mathrm{CFU} / \mathrm{g}$ ). Aspergillus sp. occurred in $5.4 \%$ of the samples (range from $5.0 \times 10^{2}$ to $\left.5.0 \times 10^{4} \mathrm{CFU} / \mathrm{g}\right)$, Cladosporium sp. in $32.4 \%$ (range from $5.0 \times 10$ to $5.0 \times 10^{5} \mathrm{CFU} / \mathrm{g}$ ), and yeasts in $78.4 \%$ of the samples (range from $4.0 \times$ $10^{2}$ to $\left.5.6 \times 10^{5} \mathrm{CFU} / \mathrm{g}\right)$.

Fumonisins $\left(\mathrm{FB}_{1}+\mathrm{FB}_{2}\right)$ were detected in 21 out of the 37 hybrids studied (56.8\%), in the concentration range of 0.05 to $2.67 \mu \mathrm{g}$ of FB/g of corn (Table 5). The hybrids AS32, XL360, and DINA766 (Table 5) were fumonisin positive but negative for Fusarium sp. It is interesting to note that these freshly collected samples were highly infected by yeast (Table 5), which has been reported to interfere with Fusaria growth $(6,18,28)$.

The correlation between contamination pattern and AI content was evaluated using Fusaria count, fumonisin data, and AI against $F$. verticillioides (Fig. 4). Consequently, the 37 corn hybrids were grouped into six classes of AI levels for a correlation test. However, although correlation showed a tendency in the decrease of Fusaria count $(r=$ $-0.48)$ relative to fumonisin content $(r=$ -0.37), when the AI level was high, statistical analysis indicated that no correlation existed either between AI 


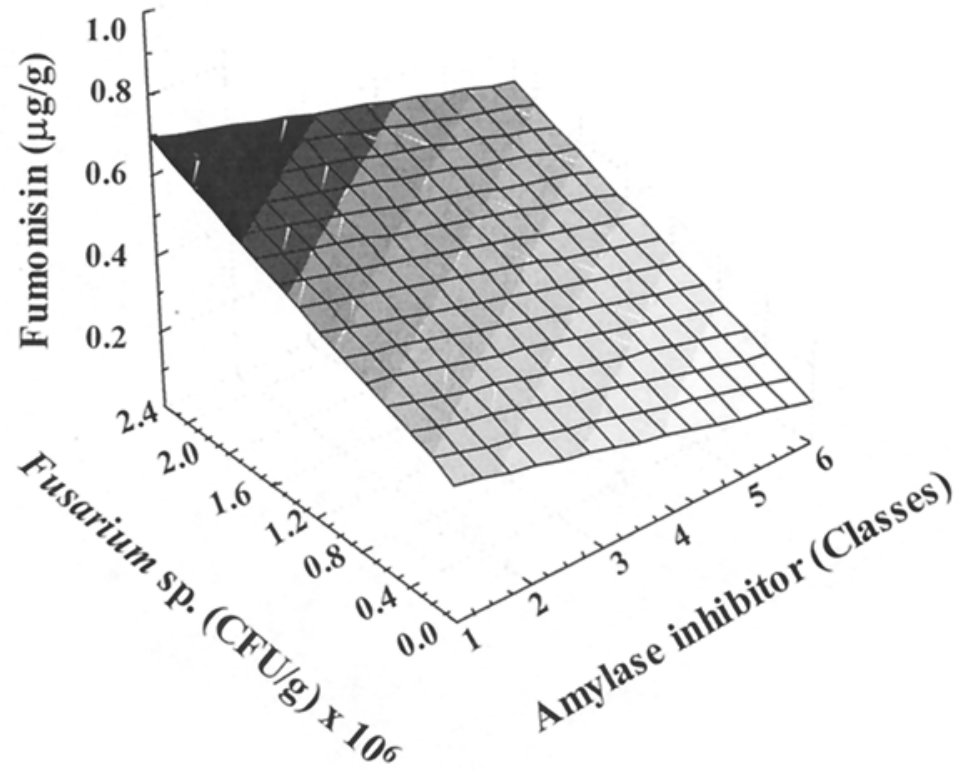

Fig. 4. Effect of Fusarium moniliforme amylase inhibitor on Fusarium sp. count and fumonisin content.

and fumonisin level or between AI and Fusarium sp. count.

\section{DISCUSSION}

Amylase inhibitors have been extensively studied, mainly as resistance factors to insects. However, much less information is available on their role as resistance factors to fungi. Recently, Fakhoury and Woloshuk (9) have reported a $38-\mathrm{kDa} \mathrm{AI}$ from Lablab purpureus active against $A$. flavus amylase and also against its growth.

The new AI herein described differs from the 12- and 14-kDa inhibitors previously reported, in both molecular mass and specificity; and from the $22 \mathrm{kDa}$ in the $\mathrm{pI}$, since the 22-kDa protein showed a basic $\mathrm{pI}$ $(13,17)$, and recently Gómez-Leyva and Blanco-Labra (13) demonstrated that this pure protein lacks inhibitory activity. This inhibitor also shows a wide range of inhibition, showing interesting potential for the control of some agriculturally important insect pests.

González et al. (14), in a similar study in Argentina on corn, also detected a predominance of Fusarium sp., in both genus frequency and relative density, followed by Penicillium sp., Alternaria sp., Aspergillus sp., Cladosporium sp., Nigrospora sp., and Trichoderma sp. Fusaria prevailed in the internal seedborne mycoflora, while Penicillium $\mathrm{sp}$. was the most common fungus in the external mycoflora. Other studies carried out in different countries demonstrated that $F$. verticillioides have been found to be important primary fungi of field and stored corn in Brazil (15), the United States (23), Honduras (19), the European Community (8), and Italy (22).

Table 5 shows that the fumonisin concentration in the tested materials was lower than the concentration found in previous studies $(8,22,23,25)$, including our own $(15,27)$. However, these levels are still under the range reported by Munkvold and McKean (24) and Shephard et al. (36). A possible explanation for this could be that the experimental field plot used was kept under more controlled conditions.

Nevertheless, evidence suggesting that inhibitors of amylases contribute to resistance to fungal pathogens has been shown by Fakhoury and Woloshuk (9). This new corn AI, which in the laboratory has been shown to be active against $F$. verticillioides amylase, when measured in the field under the conditions tested, showed no correlation to fungal growth or with fumonisin production. This lack of effect in vivo could be influenced by the conditions used, the contamination by yeast, or else could be the result of a fungal detoxification such as a proteolytic activity acting on this protein. However, the specificity shown against some important insect and fungal amylases opens new perspectives for its application.

\section{ACKNOWLEDGMENTS}

This work was financed by National Council of Scientific and Technological Development-CNPq (Brazil), and Concyteg-Mexico (project 00-03). The authors thank the National Council of Scientific and Technological Development-CNPq for a doctoral fellowship to Edson L. Z. Figueira (Process 144787/1998-9), and for a research productivity fellowship to Elisa Y. Hirooka; and the CAPES Foundation for Doctoral Sandwich fellowship to Edson L. Z. Figueira (Process BEX0119/01-6).

\section{LITERATURE CITED}

1. Blanco-Labra, A., Chagolla-Lopez, A., Martínez-Gallardo, N., and Valdes-Rodriguez, S. 1995. Further characterization of the 12 $\mathrm{kDa}$ protease/alpha-amylase inhibitor present in maize seeds. J. Food Biochem. 19:27-41.

2. Blanco-Labra, A., and Iturbe-Chiñas, F. A. 1981. Purification and characterization of an $\alpha$-amylase inhibitor from maize (Zea maize). J. Food Biochem. 5:1-17.

3. Bloom, H., Beier, H., and Gross, H. S. 1987. Improved silver staining of the plant protein, RNA and DNA in polyacrylamide gels. Elec-

\section{Fumonisin $(\mu \mathrm{g} / \mathrm{g})$}

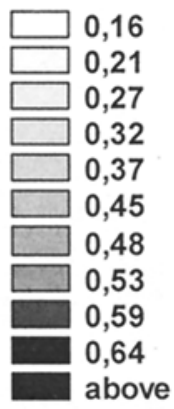

trophoresis 8:93-99.

4. Bradford, M. M. 1976. A rapid and sensitive method for the quantification of microgram quantities of protein utilizing the principle of protein-dye binding. Anal. Biochem. 72:248254.

5. Bullerman, L. B., and Draughon, F. A. 1994. Fusarium moniliforme and fumonisin symposium - introduction. J. Food Prot. 57:513.

6. Camilo, S. B., Ono, C. J., Ueno, Y., and Hirooka, E. Y. 2000. Anti-Fusarium moniliforme activity and fumonisin biodegradation by corn and silage microflora. Braz. Arch. Biol. Technol. 43:159-164.

7. Chen, Z.-Y., Brown, R. L., Russin, J. S., Lax, A. R., and Cleveland, T. E. 1999. A corn trypsin inhibitor with antifungal activity inhibits Aspergillus flavus $\alpha$-amylase. Phytopathology 89:902-907.

8. Doko, M. B., Rapior, S., Visconti, A., and Schjoth, J. E. 1995. Incidence and levels of fumonisin contamination in maize genotypes grown in Europe and Africa. J. Agric. Food Chem. 43:429-434.

9. Fakhoury, A. M., and Woloshuk, C. P. 2001. Inhibition of growth of Aspergillus flavus and fungal $\alpha$-amylases by a lectin-like protein from Lablab purpureus. Mol. Plant-Microbe Interact. 14:955-961.

10. Figueira, E. L. Z., and Hirooka, E. Y. 2000. Culture medium for amylase production by toxigenic fungi. Braz. Arch. Biol. Technol. 43:461-467.

11. Gatehouse, A. M. R., Hilder, V. A., and Gatehouse, J. A. 1992. Control of insect pests by plant genetic engineering. Proc. Royal Soc. Edinburgh, 99B (3/4):51-60.

12. Gomes, V. M., and Xavier-Filho, J. 1994. Biochemical defenses of plants. Arq. Biol. Tecnol. 37:371-383.

13. Gómez-Leyva, J. F., and Blanco-Labra, A 2001. Bifunctional $\alpha$-amylase/trypsin inhibitor activity previously ascribed to the $22 \mathrm{kDa}$ TL protein, resided in a contaminant protein of $14 \mathrm{kDa}$. J. Plant Physiol. 158:177-183.

14. González, H. H. L., Resnik, S. L., Boca, R. T., and Marasas, W. F. O. 1995. Mycoflora of Argentinian corn harvested in the main production area in 1990. Mycopathologia 130:29-36.

15. Hirooka, E. Y., Yamaguchi, M. M., Aoyama, S., Sugiura, Y., and Ueno, Y. 1996. The natural occurrence of fumonisins in Brazilian corn kernels. Food Addit. Contam. 13:173-183. 
16. Huang, Z., White, D. G., and Payne, G. A. 1997. Corn seed proteins inhibitory to Aspergillus flavus and aflatoxin biosynthesis. Phytopathology 87:622-627.

17. Huynh, Q. K., Borgmeyer, J. R., and Zobel, J. F. 1992. Isolation and characterization of a 22 $\mathrm{kDa}$ protein with antifungal properties from maize seeds. Biochem. Biophys. Res. Co. 182:1-15.

18. Janisiewicz, W. J., Peterson, D. L., and Bors, R. 1994. Control of storage decay of apples with Sporobolomyces roseus. Plant Dis. 78:466-470.

19. Julian, A. M., Wareing, P. W., Philips, S. I., Medlock, V. F. P., MacDonald, M. V., and Río, L. E. 1995. Fungal contamination and selected mycotoxins in pre- and post-harvest maize in Honduras. Mycopathologia 129:516.

20. Kedera, C. J., Plattner, R. D., and Desjardins, A. E. 1999. Incidence of Fusarium spp. and levels of fumonisin $B_{1}$ in maize in western Kenya. Appl. Environ. Microbiol. 65:41-44.

21. Kuiper-Goodman, T., Scott, P. M., and Watanabe, H. 1987. Risk assessment of the mycotoxin zearalenone. Reg. Toxicol. Pharmacol. 7:253-306

22. Logrieco, A., Moretti, A., Ritieni, A., Bottalico, A., and Corda, P. 1995. Occurrence and toxigenicity of Fusarium proliferatum from preharvest maize ear rot, and associated mycotoxins, in Italy. Plant Dis. 79:727-731.

23. Munkvold, G. P., and Desjardins, A. E. 1997. Fumonisins in maize: Can we reduce their occurrence? Plant Dis. 81:556-565.

24. Munkvold, G. P., and McKean, J. 1994. Field survey for corn ear rots and mycotoxin in 1993. Pages 5901-5904 in: Iowa State Univ. Vet. Med. Ext. Newsl. 402-V751.

25. Murphy, P. A., Rice, L. G., and Ross, P. F.
1993. Fumonisin $B_{1}, B_{2}$ and $B_{3}$ content of Iowa, Wisconsin and Illinois corn and corn screenings. J. Agric. Food Chem. 41:263-266.

26. Norred, W. P., and Voss, K. A. 1994. Toxicity and role of fumonisins in animal diseases and human esophageal cancer. J. Food Prot. 57:522-527.

27. Ono, E. Y. S., Ono, M. A., Funo, F. Y., Medina, A. E., Oliveira, T. C. R. M., Kawamura, O., Ueno, Y., and Hirooka, E. Y. 2001. Evaluation of fumonisins-aflatoxins cooccurrence in Brazilian corn hybrids by ELISA. Food Addit. Contam. 18:719-729.

28. Petterson, S., Hansen, M. W., Axberg, K., Hult, K., and Schnurer, J. 1998. Ochratoxin A accumulation in cultures of Penicillium verrucosum with the antagonistic yeast Pichia anomala and Saccharomyces cerevisiae. Mycol. Res. 102:1003-1008.

29. Sabino, M., Prado, G., Inomata, E. I., Pedroso, M. O., and Garcia, R. V. 1989. Natural occurrence of aflatoxin and zearalenone in maize in Brazil. Part II. Food Addit. Contam. 6:327-331.

30. Samson, R. A., Hoeskstra, E. S., Frisead, J. C., and Filtenborg, O. 1995. Introduction to foodborn fungi. Centraalbureau voor Schimmelcultues, Netherlands.

31. SAS Institute. 1988. SAS User's Guide. Statistics. SAS Institute, Cary, NC.

32. Schägger, H., and Von Jagow, G. 1987. Tricine-sodium dodecyl sulfate-polyacrylamide gel electrophoresis for the separation of proteins in the range from 1 to $100 \mathrm{kDa}$. Anal. Biochem. 166:368-379.

33. Scott, G. E., and Zummo, N. 1994. Kernel infection and aflatoxin production in maize by Aspergillus flavus relative to inoculation and harvest dates. Plant Dis. 78:123-125.

34. Scott, P. M. 1993. Fumonisins. Int. J. Food
Microbiol. 18:257-270.

35. Shephard, G. S., Sydenham, E. W., Thiel, P G., and Gelderblom, W. C. A. 1990. Quantitative determination of fumonisins $\mathrm{B}_{1}$ and $\mathrm{B}_{2}$ by high-performance liquid chromatography with fluorescence detection. J. Liq. Chromatogr. 13:2077-2087.

36. Shephard, G. S., Thiel, P. G., Stockenstrom, S., and Sydenham, E. W. 1996. Worldwide survey of fumonisin contamination of corn and corn-based products. J. AOAC Intern. 79:671-687.

37. Ueno, Y. 2000. Risk of multiple exposure to natural toxins. Mycotoxins 50:13-22.

38. Ueno, Y., Aoyama, S., Sugiura, Y., Wang, D. S., Lee, U. S., Hirooka, E. Y., Hara, S., Karet, T., Chen, G., and Yu, S. Z. 1993. A limited survey of fumonisins in corn and corn-based products in Asian countries. Mycotoxin Res. 9:27-34.

39. Wang, J. S., Huang, T., Su, J., Liang, F., Wei, Z., Liang, Y., Luo, H., Kuang, S. Y., Qian, G. S., Sun, G., He, X., Kensler, T. W., and Groopman, J. D. 2001. Hepatocellular carcinoma and aflatoxin exposure in Zhyqing Village, Fusui County, People's Republic of China. Cancer Epidemiol. Biomarkers 10:143-146.

40. Watson, S. A., and Ramstad, P. E., eds. 1987. Corn: Chemistry and Technology. Ch. 5 and 6. American Association of Cereal Chemists, St. Paul, MN.

41. Wilson, J. J., and Ingledew, W. M. 1982. Isolation and characterization of Schwanniomyces alluvius amylolytic enzymes. Appl. Environ. Microbiol. 44:301-307.

42. Wong, J. J., and Hsieh, D. P. H. 1976 Mutagenicity of aflatoxins related to their metabolism and carcinogenic potential. Proc. Natl. Acad. Sci. USA 73:2241. 